AT-TAJDID: Jurnal Pendidikan Dan Pemikiran Islam

(p-ISSN: 2548-5784 le-ISSN: 2549-2101)

Vol. (4)(01), (Januari-Juni)(2020), (Halaman)(46-55)

Doi: http://dx.doi.org/10.24127/att.v4i01.1218

\title{
PENGEMBANGAN MODEL IBRAH MAUIDZAH DALAM PEMBELAJARAN PAI UNTUK MENINGKATKAN KARAKTER SISWA
}

\author{
Asep Abdul Aziz, ${ }^{1}$ \\ Universitas Islam Negeri Sunan Gunung Djati \\ asepabdulaziz1993@gmail.com \\ Nurti Budiyanti ${ }^{2}$ \\ Universitas Islam Negeri Sunan Gunung Djati \\ nurtibudiyanti@upi.edu \\ Aan Hasanah ${ }^{3}$ \\ Universitas Islam Negeri Sunan Gunung Djati \\ aanhasanah@uinsgd.ac.id
}

\begin{abstract}
ABSTRAK
Terdapat indikasi kuat mengenai hilangnya nilai-nilai luhur yang melekat pada anak-anak sekolah, seperti nilai kejujuran, kesantunan, kebersamaan, dan sebagainya. Oleh sebab itu, perlu ada upaya untuk menjadikan nilai-nilai itu kembali menjadi karakter yang tertanam dalam pribadi bangsa kita. Salah satu upaya ke arah itu adalah memperbaiki sistem pendidikan dengan menitikberatkan pada pendidikan keagamaan ataupun kegiatan yang bernilai keagamaan sehingga terbentuk akhlak yang terpuji. Tujuan penelitian ini adalah untuk mengkaji mengenai model Ibrah Mauidzah melalui pembelajaran PAI dalam meningkatkan karkater siswa. Metode yang digunakan adalah kepustakaan atau library research, yakni penelitian yang dilakukan melalui pengumpulan data atau karya tulis ilmiah dengan objek penelitian atau pengumpulan data bersifat kepustakaan. Model Ibrah Mauidzah merupakan penyampaian materi pendidikan dengan perkataan yang lemah lembut namun tegas dan benar berdasarkan ilmu dan menggunakan kata-kata bijak sesuai dengan tingkat kepandaian dan bahasa yang dikuasai peserta didik. Memberikan nasihat dan perumpamaan yang menyentuh jiwa sesuai dengan taraf pengetahuan.
\end{abstract}

Kata Kunci: Model, Ibrah Mauidzah, Karakter

\begin{abstract}
There are strong indications of the loss of noble values inherent in school children, such as the value of honesty, politeness, togetherness, and so on. Therefore, there needs to be an effort to make these values back into a character that is embedded in the person of our nation. One effort
\end{abstract}


in that direction is to improve the education system by focusing on religious education or activities of religious value to form commendable morals. The purpose of this study was to examine the model of Ibrah Mauidzah through PAI learning in improving student character. The method used is the library or library research, namely research carried out through data collection or scientific papers with research objects or library data collection. The model of Ibrah Mauidzah is the delivery of educational material with gentle but firm and true words based on knowledge and using wise words following the level of intelligence and language mastered by students. Give advice and parables that touch the soul following the level of knowledge.

Keywords: Model, Ibrah Mauidzah, Character

\section{A. PENDAhuluan}

Salah satu permasalahan yang mencuat ke permukaan di dunia pendidikan di Indonesia sekarang ini adalah yang berhubungan dengan pendidikan karakter. Artinya pendidikan yang memberikan nilainilai, budi pekerti, ataupun pendidikan yang membentuk watak seseorang dengan tujuan mengembangkan kemampuan siswa agar menjadi lebih baik dan mampu mengimplementasikannya dalam kehidupan sehari-hari dengan sepenuh hati dikarenakan baik buruknya suatu negara tergantung dari karakter bangsanya (Esmi Tsalsa Sofiawati, 2018).

Orientasi pendidikan yang cenderung mengedepankan pengembangan dimensi kognitif dan abai terhadap pengembangan dimensi afektif akan menciptakan ketimpangan antara kematangan intelektual dan kematangan pribadi. Peserta didik akan mempunyai pengetahuan luas namun kurang memiliki sistem nilai yang menjadi pedoman untuk berperilaku. Sebagai akibatnya, ia akan mudah terseret ke dalam praktik penyimpangan moral karena sistem nilai yang seharusnya menjadi patokan dalam berperilaku belum tertanam kuat di dalam dirinya. Sehingga pada akhirnya, pendidikan akan melahirkan lulusan spesialis yang kering nilai dan kurang peduli dengan lingkungan sekitarnya (Sigit Priatmoko, n.d.).

Lahirnya pendidikan sekular yang pragmatis dan ekonomis tentunya mempengaruhi pada perilaku anak didik tersebut. Sehingga timbul perilaku-perilaku tak terdidik, jauh dari sopan santun, tidak mencerminkan siswa yang berpendidikan. Terjadinya aksi tawuran yang kian hari semakin menjadi budaya di kalangan pelajar. Munculnya pelajar-pelajar yang terlibat aksi anarkis dan kriminal di mediamedia massa adalah bukan berita baru lagi. Lalu akan dibawa kemana dan dibentuk seperti apa wajah pendidikan ini jika siswasiswanya kerap menjadi sasaran berita hangat di masyarakat dan media karena ulah dan perilaku yang tak beradab dan jauh dari cerminan akhlakul karimah (Muhajir Syarif, n.d.).

Pendidikan karakter merupakan salah satu solusi untuk membentuk pribadi peserta didik yang lebih baik. Pendidikan karakter di sekolah merupakan salah satu program yang dicanangkan oleh pemerintah Indonesia melalui Kemeterian Pendidikan sejak tahun 2010. Program ini dimaskud 
untuk menanamkan, membentuk dan mengembangkan kembali nilai-nilai karakter bangsa. Karena pendidikan tidak hanya mendidik peserta didiknya untuk menjadi manusia yang cerdas dengan intelektual tinggi saja, akan tetapi juga membangun pribadi dengan akhlak yang mulia. Orangorang yang memiliki karakter baik dan mulia secara individu dan sosial ialah mereka yang memiliki akhlak, moral dan budi pekerti yang baik. Mengingat pentingnya karakter dalam diri, maka pendidikan memiliki tanggung jawab yang begitu besar untuk dapat menanamkan melalui proses pembelajaran (Ahsanulkhaq, 2019).

Abdul Majid berpandangan bahwa kegagalan pendidikan agama yang diterapkan oleh lembaga pendidikan selama ini adalah karena PAI lebih berkonsentrasi pada persoalan teoritis keagamaan yang bersifat kognitif dan kurang concern pada persoalan bagaimana mengubah pengetahuan agama yang kognitif menjadi "makna" dan "nilai" yang perlu diinternalisasikan dalam diri peserta didik lewat berbagai cara, media, maupun forum. Pembahasannya sejak dulu hanya berkutat seputar persoalan-persoalan agama yang bersifat ritual-formal serta aqidah/teologi yang terkesan eksklusif. Persoalan agama yang lebih subtansial tidak terkuak secara kritis, misalnya kesalehan dalam konteks sosial. Akibatnya, pesan agama yang bersifat pereneal terbenam dibalik keberagamaan yang eksklusif. Teks-teks dibaca tiap hari namun maknanya yang hakiki terbengkalai. Sistem pendidikan nasional kita selama ini diyakini lebih mengarah pada sisi kognitif, sedangkan aspek afeksi dan psikomotor menjadi terabaikan begitu saja, tetapi sikap dan perilakunya buruk yang tidak mencerminkan capaian nilai PAI yang telah dipelajarinya (Munif, 2017).

Dengan demikian pendidikan karakter perlu dikembangkan dalam diri siswa untuk menumbuhkan perilaku yang sesuai dengan ajaran agama Islam yang berlandaskan AlQur'an dan Hadits. Banyaknya siswa yang bertindak tidak sesuai dengan nilai-nilai agama Islam yang berlaku baik itu di sekolah maupun di masyarakat, maka pendidikan karakter perlu diterapkan dan direalisasikan di sekolah. Salah satu faktor penting dalam meningkatkan pendidikan karakter siswa adalah model Ibrah Mauidzah.

Model Ibrah Mauidzah merupakan penyampaian materi pendidikan dengan perkataan yang lemah lembut namun tegas dan benar berdasarkan ilmu dan menggunakan kata-kata bijak sesuai dengan tingkat kepandaian dan bahasa yang dikuasai peserta didik. Memberikan nasihat dan perumpamaan yang menyentuh jiwa sesuai dengan taraf pengetahuan (Nurdin, n.d.).

Model Ibrah Mauidzah menekankan pada pemberian nasihat-nasihat dan perhatian khusus kepada para siswa atau anak mereka dalam rangka pembinaan karakter. Cara ini juga sangat membantu dalam memotivasi siswa untuk memiliki komitmen dengan aturan-aturan atau nilainilai akhlak mulia yang harus di terapkan (Siska Kusumawati, 2018).

Tulisan ini mencoba menawarkan sebuah alternatif solusi yang dapat digunakan sekolah tidak hanya untuk 
memperkuat eksistensinya namun juga untuk meningkatkan kualitas lulusannya. Solusi tersebut adalah dengan melakukan pengembangan dan penerapan model Ibrah mauidzah dalam meningkatkan karakter siswa. Nilai-nilai karakter seperti sopan santun, ramah, gotong royong, tawadlu', dan sebagainya yang mulai memudar di kalangan siswa perlu direvitalisasi. Sehingga siswa diharapkan tidak hanya memiliki kematangan profesionalitas namun juga memiliki kematangan spiritualitas.

\section{B. METODOLOGI}

1. Jenis Penelitian

Dilihat dari jenis penelitiannya, penelitian yang digunakan adalah penelitian kepustakaan atau library research, yakni penelitian yang dilakukan melalui pengumpulan data atau karya tulis ilmiah dengan objek penelitian atau pengumpulan data bersifat kepustakaan (Mustika Zed, 2004). Metode pengumpulan data penelitian ini diambil dari sumber data. Maksudnya sumber data dalam penelitian ini adalah subjek dari mana data tersebut diperoleh.

Dalam penelitian ini yang menjadi sumber data adalah sebagai berikut:

a. Sumber data Primer

Sumber data primer adalah sumbersumber yang memberikan data secara langsung dari tangan pertama atau merupakan sumber asli. Dalam penelitian ini yang menjadi sumber datanya berupa buku, jurnal, majalah, dll.

b. Sumber Data Sekunder

Sumber data sekunder maksudanya sumber-sumber lain yang diperoleh dari sumber primer. Dalam penelitian ini sumber data sekunder berupa buku- buku lain yang berhubungan dengan bahasan penelitian ini.

\section{Teknik Analisis Data}

Setelah leseluruhan data terkumpul, maka langkah selanjutnya penulis menganalisa data tersebut sehingga ditarik suatu kesimpulan. Untuk memperoleh hasil yang benar dan tepat dalam menganalisa data, penulis menggunakan teknik analisis isi. Analisis isi (Content Analysis) adalah penelitian yang bersifat informasi tertulis atau tercetak di media massa untuk menemukan karakteristik pesan yang dilakukan secara objektif dan sistematis (Lexy J. Moleong, 2002).

\section{HASIL DAN PEMBAHASAN}

\section{Model Pembelajaran}

Model pembelajaran merupakan suatu kerangka konseptual yang berisi prosedur sistematik dan mengorganisasikan pengalaman belajar siswa untuk mencapai tujuan belajar tertentu yang berfungsi sebagai pedoman bagi guru (Muizaddin \& Santoso, 2016).

Model pembelajaran, menurut Isjoni, merupakan strategi yang digunakan guru untuk meningkatkan motivasi belajar, sikap belajar di kalangan siswa, mampu berpikir kritis, memiliki keterampilan sosial, dan pencapaian hasil pembelajaran yang berisi strategi-strategi pilihan guru untuk tujuantujuan tertentu di kelas (Sundari, 2015).

Para ahli biasanya menyusun model pembelajaran berdasarkan prinsip-prinsip pembelajaran, teori-teori psikologis, analisis system, atau teori-teori lain yang mendukung. Joyce \& Weil mempelajarai model-model pembelajaran berdasarkan 
teori belajar yang dikelompokkan menjadi empat model pembelajaran yaitu: (1) model interaksi social, dalam model ini siswa dituntut untuk aktif berinteraksi dengan lingkungan belajarnya; (2) model pemrosesan informasi, menuntut siswa untuk aktif dalam memilih dan mengembangkan materi yang akan dipelajarinya; (3) model personal, yaitu menuntut siswa untuk mampu mengeksplorasi dan mengaktualisasikan kemampuannya dalam kegiatan pembelajaran; (4) model mudifikasi tingkah laku, yaitu: siswa harus mampu mengembangkan kemampuannya melalui tugas-tugas belajar, prembentukan prilaku aktif dan manipulasi lingkungan untuk kepentingan belajar (Abdullah, 2017).

\section{Ibrah Mauidzah}

Kata "Ibrah Mauidzah" berasal dari akar kata "abara al-ra'yu" yang artinya menfasirkan mimpi dan mengetahui apa yang akan terjadi pada orang yang bermimpi. Sedangkan "abara al-wadiya" atau "abara al-nahr" berarti menyeberangi lembah atau sungai dari tepi ke tepi lain yang berlawanan. Adapun "Mauidzah" mengandung makna nasihat dimana kata tersebut sejalan dengan makna kata “Wa'zha, ya'izhu, wa'zhan, wazhatan, dan wa mauizhan" yang berarti memberi nasihat (Kisnanziar, 2014).

An-Nahlawi menjelaskan mengenai pengertian 'ibrah secara istilah yaitu: 'Ibrah adalah salah satu mașdar (pokok kata) dari 'abara. Sedangkan secara istilah 'ibrah ialah suatu kondisi untuk mengetahui intisari sesuatu perkara yang disaksikan, diperhatikan, diinduksi, ditimbang- timbang, diukur, dan diputuskan oleh manusia secara nalar, sehingga kesimpulannya dapat mempengaruhi hati menjadi tunduk kepadanya, lalu hal itu mendorongnya kepada perilaku berpikir dan sosial yang sesuai. Sedangkan Mauidzah mengandung makna mengingatkan akan apa yang dapat melembutkan qalbunya, yang berupa pahala dan siksa, sehingga dia menerima nasihat (Maknun, Supriadi, dan Indonesia 2017).

Rasyid Ridha mengartikan mauidzah adalah nasehat peringatan atas kebaikan dan kebenaran dengan jalan apa saja yang dapat menyentuh hati dan membangkitkannya untuk mengamalkan dalam al-Qur'an juga menggunakan kalimat-kalimat yang menyentuh hati untuk mengarahkan manusia kepada ide yang dikehendakinya. Inilah yang kemudian dikenal dengan nasehat (Darojah, 2016).

Dalam al-Qur'an sendiri ibrah mauidzah diartikan sebagai upaya untuk mengambil pelajaran dari pengalaman orang lain atau peristiwa yang terjadi pada masa lampau melalui suatu proses berfikir secara mendalam sehingga menimbulkan kesadaran pada diri seseorang dengan cara tutur kata yang berisi nasihat dan peringatan baik buruknya sesuatu (Tisnia, 2013).

\section{Pendidkan Karakter}

Karakter adalah bentuk watak, tabiat, akhlak yang melekat pada pribadi seseorang yang terbentuk dari hasil internalisasi yang digunakan sebagai landasan untuk berpikir dan berperilaku sehingga menimbulkan suatu ciri khas pada individu tersebut (Maunah, 2016).

Secara harfiah karakter artinya "kualitas mental atau moral, kekuatan moral, nama 
atau reputasi" . Karakter berasal dari bahasa latin "kharakter", "kharassein", "kharax", dalam bahasa Inggris "character", dari charassein berarti membuat tajam, membuat dalam. Dalam kamus Poerwadarminta, karakter diartika sebagai tabiat, watak, sifatsifat kejiwaan, akhlak atau budi pekeri yang membedakan seseorang dengan orang lain. Nama dari jumlah seluruh ciri pribadi yang meliputi hal-hal seperti perilaku, kebiasaan, kesukaan, ketidaksukaan, kemampuan, kecenderungan, potensi, nilai-nilai, dan pola pemikiran (Ilviatun Navisah, 2016).

Dalam rancangan (grand design) pendidikan karakter Kementerian Pendidikan Nasional Republik Indonesia, dikatakan bahwa pendidikan karakter merupakan proses pembudayaan dan pemberdayaan nilai-nilai luhur dalam lingkungan satuan pendidikan (sekolah), lingkungan keluarga, dan lingkungan masyarakat. Nilai-nilai lurus tersebut berasal dari teori-teori pendidikan, psikologi pendidikan dan nilai sosial budaya, ajaran agama, pancasila dan UUD 1945 serta Undang-undang (UU) No 20 tahun 2003 tentang Sistem Pendidikan Nasional (Sisdiknas), serta pengalaman terbaik dan praktik nyata dalam kehidupan sehari-hari (Johansyah, 2017).

Pendidikan budaya dan karakter bangsa bertujuan untuk mempersiapkan peserta didik menjadi Warga Negara yang lebih baik, yaitu Warga Negara yang memiliki kemampuan, kemauan, dan menerapkan nilai-nilai Pancasila dalam kehidupan sebagai Warga Negara. Budaya sebagai suatu kebenaran bahwa tidak ada manusia yang hidup bermasyarakat yang tidak disadari oleh nilai-nilai budaya yang diakui masyarakat tersebut. Nilai-nilai budaya tersebut dijadikan dasar dalam pemberian makna terhadap suatu konsep dan arti dalam komunikasi antar anggota masyarakat tersebut. Posisi budaya yang demikian penting dalam pendidikan budaya dan karakter bangsa (Omeri, 2015).

\section{Peningkatan karakter Siswa Melalui Model Ibrah Mauidzah}

Pendidikan karakter merupakan suatu upaya untuk membangun budi pekerti dan sopan santun dalam kehidupan. Karakter bangsa merupakan aspek penting dari kualitas sumber daya manusia karena kualitas karakter bangsa menentukan kemajuan suatu bangsa. Karakter yang berkualitas perlu dibentuk dan dibina sejak usia dini. Usia dini merupakan masa penentuan bagi pembentukan karakter seseorang. Kegagalan penanaman kepribadian yang baik di usia dini ini akan membentuk pribadi yang bermasalah di masa dewasanya kelak.

Karakter merupakan sifat yang melekat pada setiap manusia, sebagai faktor penentu seseorang untuk bersikap dan bertingkah laku, dengan dipengaruhi oleh situasi, kondisi, dan yang dirasakan dalam hati seseorang. Karakter lebih dekat dengan akhlak, yaitu spontanitas manusia dalam bersikap atau melakukan perbuatan yang menyatu dalam diri manusia sehingga ketika muncul tidak perlu dipikirkan lagi (Gunawan, 2012).

Peningkatan karakter siswa itu tidaklah mudah, harus melalui proses pembiasaan yang dilakukan terus menerus, bukan hanya sekedar ceramah mengenai karakter tetapiu 
juga harus bisa mengajarkan dan memberi contoh yang baik bagi anak-anaknya.

Menurut Foerster ada empat ciri dasar dalam pendidikan karakter. Pertama, keteraturan interior di mana setiap tindakan diukur berdasar hierarki nilai. Nilai menjadi pedoman normatif setiap tindakan. Kedua, koherensi yang memberi keberanian, membuat seseorang teguh pada prinsip, tidak mudah terombang-ambing pada situasi baru atau takut risiko. Koherensi merupakan dasar yang membangun rasa percaya satu sama lain. Tidak adanya koherensi meruntuhkan kredibilitas seseorang. Ketiga, otonomi. Di situ seseorang menginternalisasikan aturan dari luar sampai menjadi nilai-nilai bagi pribadi. Ini dapat dilihat lewat penilaian atas keputusan pribadi tanpa terpengaruh atau desakan pihak lain. Keempat, keteguhan dan kesetiaan. Keteguhan merupakan daya tahan seseorang guna mengingini apa yang dipandang baik. Dan kesetiaan merupakan dasar bagi penghormatan atas komitmen yang dipilih (Kiromim Baroroh, 2011).

Salah satu upaya dalam peningkatan karakter siswa adalah melalui model Ibrah Mauidzah, maksudnya peningkatan karakter siswa melalui nasihat-nasihat yang baik dengan mencontohkan pengalamanpengalam masa lalu dengan bahasa yang santun sehingga mampu diserap oleh siswa dan diamalkan dalam kehidupan sehari-hari.

Model Ibrah Mau"idhah yang dalam bahasa Indonesia sering diartikan" Pelajaran yang baik". Ibnu Mandzur menjelaskan, AlMau'idhoh bisa diartikan juga memberi nasihat, memberi peringatan kepada seseorang yang bisa membawa taubat kepada Allah SWT. Pengertiannya secara istilah menurut Imam Abdullah bin Ahmad An-Nasafî adalah: Al-Mau"idhatul adalah perkataan yang tidak tersembunyi bagi mereka, bahwa engkau memberikan nasihat dan menghendaki manfaat kepada mereka atau dengan Al- Qur'an (Ipah Latipah, 2016).

Ada beberapa hal yang harus diperhatikan oleh para pendidik dalam menggunakan metode nasihat: 1) memberi nasihat dengan perasaan cinta dan kelembutan. Nasihat orang-orang yang penuh kelembutan dan kasih sayang mudah diterima dan mampu merubah kehidupan manusia, 2) menggunakan gaya bahasa yang halus dan baik, 3) pendidik harus menyesuaikan diri dengan aspek tempat, waktu, dan materi serta kondisi peserta didik, 4) menyampaikan hal-hal yang utama dan penting (Ipah Latipah, 2016).

Langkah-langkah model Ibrah Mauidzah dalam meningkatkan karakter siswa dalam pembelajaran PAI adalah sebagai berikut:

1) Tahap Pra Instruksional

Hal yang sangat penting dalam tahap ini adalah menyusun konsep yang akan disajikan sesuai dengan pokok bahasan termasuk landasan-landasannya dan menginvertariskan jenis-jenis ibrah yang disesuaikan dengan pokok bahasan yang disajikan.

2) Tahap Intruksional

- Tahap orientasi. Pada tahap ini guru menjelaskan pokok bahasan dan konsep-konsep dasar yang akan disajikan

- Penyajian Ibrah. Pada tahap ini pendidik membawakan Ibrah Yang Telah ditentukan 
sebelumnya, baik yang diambil dari ayat al-Qur'an ataupun dari peristiwa lain.

- Tahap Meyakinkan. Pada tahap ini pendidik berupaya untuk mengerahkan para sisiwa pada ibrah melalui pertanyaan atau perbandingan pada hal yang lebih dekat dengan siswa

- Tahap Internalisasi. Pada tahap ini guru membawa siswa pada penghayatan nilai-nilai yang terkandung dalam dalam setiap bentuk ibrah

- Tahap Evaluasi. Tahap ini dimaksudkan untuk mengkaji kembali apa yang telah disampaikan guru kepada siswa

- Tahap Penyimpulan. Tujuan pedagogis dari Ibrah adalah mengantarkan pendengar (siswa) kepada kepuasan berfikir akan salah satu perkara aqidah.

- Tahap Akhir. Pada tahap ini pendidik memberikan tugas (pekerjaan rumah) (Kisnanziar, 2014).

Model Ibrah mauidzah yang digunakan dalam praktik pendidikan terutama dalam proses peningkatan karakter siswa intinya adalah untuk mencapai tujuan pendidikan secara efektif. Kajian tentang model pembelajaran semakin berkembang. Hal ini dikarenakan juga semakin kompleksnya perkembangan pendidikan dengan segala tantangannya. Sementara harapan dan citacita pendidikan semakin tinggi. Individuindvidu yang mumpuni dari berbagai aspek tidak hanya kecerdasam intelektual melainkan kecerdasan moral, sosial, emosi, spiritual masih menjadi gaung pendidikan di negeri ini, cita-cita besar dari output pendidikan di Indonesia.

\section{KESIMPULAN}

Model Ibrah Mau"idhah merupakan model pemberian nasihat yang baik dengan cara yang baik yang dapat dipahami dan diterima oleh siswa. Dalam aplikasinya, model ini bukanlah model yang baru. Bahkan dapat dikatakan bahwa guru-guru cenderung menggunakan model nasihat terhadap siswanya. Namun, terkadang nasihat itu menjadi hal yang diabaikan oleh siswa. Untuk itu, perlu diperhatikan bahwa kekuatan nasihat itu terletak pada sisi pendidik (pemberi nasihat). Beberapa hal yang harus diperhatikan oleh para pendidik dalam menggunakan model Ibrah Mauidzah yaitu (1) memberi nasihat dengan perasaan cinta dan kelembutan. (2) menggunakan gaya bahasa yang halus dan baik. (3) pendidik harus menyesuaikan diri dengan aspek tempat, waktu, dan materi serta kondisi siswa dan (4) menyampaikan hal-hal yang utama dan penting.

\section{E. DAFTAR PUSTAKA}

Abdullah. (2017). Pendekatan dan Model Pembelajaran yang Mengaktifkan Siswa. Edureligia, 01(01), 45-62.

Ahsanulkhaq, M. (2019). Membentuk Karakter Religius Peserta Didik Melalui Metode Pembiasaan. Jurnal Prakarsa Paedagogia, 2(1), 21-33.

Darojah, S. (2016). Metode Penanaman Akhlak dalam Pembentukan Perilaku Siswa MTs N Ngawen Gunungkidul. 1(November), 233-244.

Esmi Tsalsa Sofiawati, F. (2018). Penguatan

Pendidikan Karakter Melalui

Pendidikan Agama Islam di Sekolah 
Dasar. Prosiding Seminar Nasional, 280-285.

Gunawan, I. (2012). Pendidikan karakter di

Tingkat Sekolah Dasar Meretas

Sekolah Humanis Untuk Mendesain

Siswa Sekolah Dasar (SD) yang Cerdas dan Berkarakter. Prosiding Seminar Nasional Dan Call For Papers.

Ilviatun Navisah. (2016). Pendidikan Karakter Dalam Keluarga. Universitas Islam Negeri Maulana Malik Ibrahim Malang.

Ipah Latipah. (2016). Implementasi Metode Al-Hikmah, Al- Mau'idhah Al Hasanah, Dan Al-Mujadalah Dalam Praktik Pendidikan (. Jurnal Ilmiah Mitra Swara Ganesha, 3(2), 19-37.

Johansyah. (2017). Pendidikan Karakter Dalam Islam Kajian dari Aspek Metodologis. Jurnal Ilmiah Islam Futura, $11(1), \quad 85$. https://doi.org/10.22373/jiif.v11i1.63

Kiromim Baroroh. (2011). Upaya Meningkatkan Nilai-Nilai Karakter Peserta Didik Melalui Penerapan Metode Role Playing - Kiromim Baroroh. Jurnal Ekonomi Dan Pendidikan, 8(2), 149-163.

Kisnanziar. (2014). Metode Pendidikan Ibrah Mauidzah.

Https://Kisnanziar.Wordpress.Com/201 4/12/30/Metode-Pendidikan-Metode-

Ibrah-Mauizah/, Diakses, 14/08/20.

Lexy J. Moleong. (2002). Metodologi Penelitian Kualitatif. PT. Remaja Rosdakarya.

Maknun, L., Supriadi, U., \& Indonesia, U. P. (2017). Efektivitas Metode Ibrah Mauidzah dalam Model Pembelajaran Student teams Achievement Divisions Terhadap Prestasi Belajar Siswa Pada Mata Pelajaran Akidah Akhlak di MTS Plus Darul Hufadz Jatinangor. Indonesian Journal of Islamic Education, 4(2), 107-126.

Maunah, B. (2016). Implementasi
Pendidikan Karakter Dalam Pembentukan Kepribadian Holistik Siswa. Jurnal Pendidikan Karakter, 1, 90-101.

https://doi.org/10.21831/jpk.v0i1.8615

Muhajir Syarif. (n.d.). Pendidikan Agama Islam dalam Pembentukan karakter Bangsa. Pascasarjana IAIN Raden Patah, 1-13.

Muizaddin, R., \& Santoso, B. (2016). Model pembelajaran core sebagai sarana dalam meningkatan hasil belajar siswa ( Core learning model for improving student learning outcomes ). Jurnal Pendidikan Manajemen Perkantoran, 1(1), 224-232.

Munif, M. (2017). Strategi Internalisasi Nilai-Nilai PAI dalam Membentuk Karakter Siswa. Edureligia, 01(01), 112.

Mustika Zed. (2004). Metode Penelitian Kepustakaan. Yayasan Obor Nasional.

Nurdin. (n.d.). Implementasi Metode Pembelajaran dalam Al-Qur'an bagi Pendidik Era Milenial. In Widyaiswara BDK Provinsi Aceh (pp. 172-189).

Omeri, N. (2015). Pentingnya Pendidikan Karakter Dalam Dunia Pendidikan. Manajer Pendidikan, 9(3), 464-468.

Sigit Priatmoko. (n.d.). Implementasi Pendidikan karakter berbasis Pesantren di Madrasah. Fakultas Agama Islam Universitas Islam Darul "Ulum Lamongan, 1-19.

Siska Kusumawati. (2018). Upaya Guru dalam Pembentukan Karakter Islami Siswa melalui Kegiatana Keagamaan bagi Siswa di SMP Al Islam 1 Surakarta Tahun Pelajaran 2017/2018 ". Institut Agama Islam Negeri Surakarta.

Sundari, H. (2015). Model-Model Pembelajaran dan Pemerolehan Bahasa Kedua/Asing. Jurnal Pujangga, 1(2), 106-117.

Tisnia, T. (n.d.). Metode Ibrah dan 
Mauidzah.

Http://Ippnuteni.Blogspot.Com/2013/1

2/Metode-Ibroh-Dan-Mauidzah-Smt5.Html. 